12. Зуєва Л. С. Принципи господарського процесу: дис. канд. юрид. наук. 12.00.04. Одеса, 2012. 197 с.

13. Господарське процесуальне право України: підручник. К., 2009. 360 с.

14. Городовенко В. Принцип незалежності суддів і підкорення їх лише законові як один 3 основних принципів судочинства в Україні // Право України, 2002. № 4. С. 125.

15. Гражданский процесс / Под общей ред. К. С. Юдельсона. М., 1972. С. 33.

16. Боннер А. Т. Принцип диспозитивносги советского гражданского процессуального права. М., 1987. C. 6.

17. Юдельсон К. С. Советский гражданский процесс. М., 1956. С. 31-32.

18. Клейнман А. Ф. Советский гражданский процесс. М., 1954. С. 45.

19. Советский гражданский процесс / Под ред. М. А. Гурвича. М., 1975. С. 16-17.

20. Проблемы наук и гражданского процессуального права / Под ред. В. В. Комарова. Харьков, 2002. С. 150.

21. Тертышников В. И. Гражданский процесс (Курс лекций). Харьков, 2002. С. 14.

22. Цивільний процес України: підручник / За ред. Ю. С. Червоного. К., 2007. 392 с.

23. Цивільний процес України: підручник. Х., 2012. 496 с.

24. Юдельсон К. С. Советский гражданский процесс. М., 1956. С. 31-32.

25. Чечина Н. А. Актуальные проблемы теории и практики гражданского процесса. Л., 1979. С. 52.

26. Советский гражданский процесс / Под ред. М. А. Гурвича. М., 1975. С. 16-17.

27. Цивільний процес: навч. посіб. / А. В. Андрушко, Ю. В. Білоусов, Р. О. Стефанчук, О. І. Угриновська та ін. / За ред. Ю. В. Білоусова. К., 2006. 293 с.

28. Верховенство права (Доповідь, схвалена Венеціанською Комісією на 86 пленарному засіданні 25-26 березня 2011 року) // Право України, 2011. № 10. С. 168-184.

29. Про деякі питання практики застосування розділу VI Господарського процесуального кодексу України: Постанова Пленуму Вищого господарського суду України № 7 від 21.02.2013 року. URL: http://zakon2.rada.gov.ua/laws/show/va007600-13/page2 (дата звернення: 29.11.2017).

Drishlyuk V. Principles of implementation of commercial legal proceedings in the light of the judicial reform of 2017

The scientific article deals with the study of the principles of the implementation of commercial legal procedure in economic matters in the light of the latest changes in the commercial procedural legislation. Based on the analysis of the norms of the current commercial procedural legislation of Ukraine, the theory of commercial procedure and civil procedure law, conclusions are drawn about the content of the principles of economic legal proceedings in Ukraine and outlines the problems of applying the rules of commercial procedure legislation in the implementation of these principles. In particular, the problems associated with the implementation of the rule of law in the context of compliance with the norms of European legislation, its relationship with the principle of legality, the principle of the inadmissibility of abuse of procedural rights and other new and previously known principles of commercial litigation.

Keywords: reform, economic procedural legislation, economic legal proceedings, principles.

\title{
INTERNATIONAL VISION OF STANDARDIZATION AS A MEANS OF REGULATING ECONOMIC ENTITIES IN TERMS OF INSTABILITY AND GLOBALIZATION
}

Popovych T.,

https://doi.org/10.32849/2409-9201.2018.18.41

Researcher of Academician F. H. Burchak Scientific Research Institute of Private Law and Entrepreneurship of NALS of Ukraine

Today, standardization as one of the manifestations of socio-economic formation affects the development and state of economic entities. The main factors that directly influence the further development of national standardization are a multi-vector foreign policy aimed at Ukraine's integration into the European Union, membership in the World Trade Organization, cooperation with other countries of the world. The understanding of standardization as organizing active activity in the field of regulation is analyzed. It is indicated by the erroneousness of the verbal translation of the "technical regulation» as an activity, and not an act of regulation. This led to the false understanding that there is a system of technical regulation in Europe along with standardization. It is proposed to build a national standardization system based on requirements based on international experience. There are seven such blocks of requirements.

Keywords: standardization, technical regulation, regulation, acts of legislation, economic activity, elimination of barriers to trade, self-regulation, voluntary and mandatory requirements. 
On February 10, 2016, the new wording of the Law of Ukraine «On Technical Regulations and Conformity Assessment» defined the legal and organizational principles for the development, adoption and application of technical regulations and conformity assessment procedures provided for by them, as well as voluntary conformity assessment on the basis of international requirements. Today, standardization as one of the manifestations of socio-economic formation affects the development and state of the business people. The developments of society, the high pace of scientific and technological progress, and large-scale economic and social challenges have contributed to the increasing role of standardization. The main factors that directly influence the further development of national standardization are a multi-vector foreign policy aimed at Ukraine's integration into the European Union, membership in the World Trade Organization, cooperation with other countries of the world.

In the scientific literature, certain questions of standardization as a phenomenon, process and means of implementing the state policy in the field of legal provision of economic activity have already been the subject of research in scientific works: A. G. Bobkova, M. I. Braginsky, S. N. Bratus, M. D. Ginzburg, I. E. Zamoyskiy, G. L. Znamensky, A. S. Komarov, D. Kh. Lipnitsky, M. S. Malein, V. K. Mamutov, Yu G. Matveev, D. I. Sakoyan and many others.

The purpose of the article is to summarize the experience of standardization and to find out its significance for regulating economic activity in countries that have joined the world markets.

Ukraine, being a part of the USSR, joined the ISO, but did not take an active part in its activities, as the USSR did not aim at the globalization of its market and access to markets in other countries. At the same time, after the war, ISO is actively developing. Founded in 1947 with the slogan «friendship between peers» in 25 countries, today it has 163 members in its members.

It is also important to follow the development, when and what accents is placed on ISO (based on the materials and databases of the official website - www.iso.org [1]). In 1951, the first standard ISO / R1: 1951 was issued for standard temperature measurement for industrial length. In the future, the standard has been updated several times and today it is ISO 1: 2002 Geometrical Specifications (GPS) - Standard reference temperature for geometric product specification. That is, ISO's first steps have become standardization of requirements for units and measurement methods. The Development Committee of the developing countries (DEVCO) was created in 1961, and in 1968 it introduced a correspondent composition. This allows developing countries to be aware of the work of international standardization without full cost of membership in ISO. Similarly, there is potential benefit for developed countries as they are able to extend their requirements to other countries and expand their markets. That is, we are talking about the emergence of globalization processes in standardization.

In 1968, ISO publishes its first standard for freight containers. Cargo transportation and packaging are one of the areas where ISO is particularly active. Unification of packaging and methods of moving goods (global logistics aspects) allows for the promotion of goods around the world. End 60s of the twentieth century characterized by the end of «technical nationalism». That is, the slogan that arose at the beginning of the industrial revolution, the use of technology as a key item in strengthening the nation for its confidence in the uniqueness of the country's innovative development and the guarantees of the diffusion of technology among its own. International standardization leads to the need to spread knowledge and technology beyond the borders of individual countries.

In the early 70's of the twentieth century ISO focuses on security (environmental) issues. Particular attention is paid to the quality of air and water. At present, attention is focused on many objects: land quality, environmental management, renewable energy, etc. In 1987, ISO publishes its first quality management standard. The standards of the ISO 9000 series have gradually become part of the most famous and most popular standards. These standards are accepted by countries almost unchanged, because in the case of application symbolize the high level (class of enterprise) and the ability to rival.

Middle of 90s of the twentieth century is characterized by the development of digital technologies. ISO does not stand aside, but first creates an official page on the Internet, and since 2000 already even sells standards through the site. In those years, ISO launches a series of ISO 14000 environmental management systems. These standards provide tools for businesses and organizations that help them identify and control their environmental impact. In 2003, ISO expanded its scope to cover new technologies such as nanotechnology and biofuels. That is, we see that ISO monitors technological breakthroughs, helps to typify and unify innovation, and therefore, in 2005, the Joint Technical Committee ISO and IEC JTC1 launch ISO / IEC 27001 - the standard of information security management system. The explanation for such attention to this area is very simple - enterprises are becoming increasingly dependent on information technologies, and therefore ensuring the requirements for this system and minimizing risks becomes more and more important in corporate practice.

In 2010, ISO actively supports work on social responsibility, which leads to the launch of the ISO 26000 standard. This is the first international standard containing guidelines for social responsibility. Since social responsibility has become a daily part of business, the ISO 26000 has proven to be a global reference for organizations that care about their impact on a wide range of people. In the same years, the world 
community is thinking about energy efficiency and energy saving, which is one of the most important challenges faced by every entrepreneur. That is why ISO introduces the ISO 50001 Energy Management Standard, which provides public and private sector management strategies for energy savings, cost savings and energy efficiency improvements.

In 2016, ISO provides a powerful new tool for combating global disaster - bribery. The ISO 37001 standard is the first international benchmarking system designed to help organizations combat the risk of receiving bribes in their own operations and in all their global securities systems. It has the potential to reduce corporate risk and costs associated with bribery by creating a managed business system to prevent, detect and deal with bribery.

- ISO 37001: 2016 defines requirements and provides guidance for the establishment, implementation, support, review and improvement of the anti-bribe management system. The system can be independent or can be integrated into the general control system. ISO 37001: 2016 refers to the following activities of the organization:

- bribery in public, private and non-profit sectors;

- bribery in the organization;

- bribery of the personnel of the organization acting on behalf of the organization or in favor of it;

- bribery of business partners of the organization acting on behalf of the organization or in favor of it;

- bribery of the organization;

- bribery of the personnel of the organization in relation to the organization's activities;

- bribery of the business partners of the organization in relation to the organization's activities;

- direct and indirect bribery (for example, a bribe offered or accepted through a third party).

ISO 37001: 2016 applies only to bribery. It defines requirements and provides guidance for a management system designed to help the organization prevent, detect and respond to bribery, and enforce bribery laws and voluntary commitments that apply to its activities. ISO 37001: 2016 does not specifically deal with fraud, cartels and other anti-monopoly / competition offenses, money laundering and other activities related to corruption, although the organization may choose to extend the scope of the management system to include such activities. The requirements of ISO 37001: 2016 are general and are intended for use by all organizations (or parts of the organization), regardless of the type, size and kind of the activity, as well as in the public, private or non-profit sectors. The degree of application of these requirements depends on various factors.

Since 1962, when ISO adopted the first definition of the term "standardization», its perfection periodically took place, reflecting the development of standardization due to the level of development of scientific and technological progress. The current term in the interpretation of ISO has the following definition: standardization is an activity aimed at achieving the optimal level of regulation in a particular industry by establishing provisions for the general and reusable use of real or possible tasks [2]. This activity consists of the processes of developing, issuing and implementing standards. The important benefits of standardizing ISO / IEC Guide 2: 2004 (Standardization and Related Activities - Common Dictionary) are improving the suitability of products, processes and services for their intended purpose, preventing barriers to trade and facilitating technical cooperation [3].

The security task of standardization in official international and national documents is not explicitly mentioned, but when a separate type of document is being developed, it necessarily refers to the need to take into account security factors, since each product has an impact on the environment at all stages of its life cycle, from the extraction of resources to life-long processing and the need to reduce the potential negative impact on the environment of the product. It is recognized throughout the world, and as a practical tool for addressing these issues, as well as a tool for regulating sustainable international trade, is the guide to ISO Guide 64: 2008 «Guidelines for addressing environmental problems in commodity (production) standards» [4].

Now the business entity in the world market informally impose such blocks requirements: 1) the quality of production and management (ISO 9000 series of standards, ISO 22000); 2) safety, including environmental protection and information security (series of standards ISO 14000, ISO 27000); 3) social responsibility (a series of standards ISO 22000, the standard ISO 26000); 4) the purity of the business, including the risks of bribery (ISO standard 37001).

When the question of unification of Europe, it was founded as the European Committee for the Coordination of standards that have become the central body of the EU in this area. The future relationship between standardization and legislation at the European level has been developed and is being developed by the European Committee for Standardization (renamed from 1970) in accordance with the so-called «new approach» to technical harmonization and standards, which were introduced in 1985 (here and below analyzes the material on official site - www.cen.eu [5]). It is then that the European Union adopts supranational legislation (the EU Directive) which defines the basic requirements for security and other aspects of public interest that should be part of the goods and services sold on the single market. If necessary, the European Commission issues standardization requests (mandates) to the European Standardization Organizations (CEN, CENELEC - European Committee for Standardization in Electrical and Electronics and ETSI - the European Institute for Telecommunication Standardization) responsible for the preparation of 
technical standards and specifications, which facilitates compliance with these basic requirements. At the same times, all national authorities must recognize that all manufactured goods (and services) in accordance with harmonized standards are presumed to comply with the essential requirements of the relevant EU legislation. European standards from the beginning were and remain voluntary, and therefore there is no legal obligation for their use (EN 45020: 2006 - Standardization and related activities - General vocabulary (ISO / IEC Guide 2: 2004 [6]). Any manufacturer (or service provider) who decides not to follow a harmonized standard to prove that their products (or services) to meet other basic requirements.

Today, the European Committee for Standardization (CEN) is an association that includes participants and coordinates the national standards bodies of 34 European countries. CEN is one of the three European standardization organizations (together with CENELEC and ETSI) that are officially recognized by the European Union and the European Free Trade Association (EFTA) as responsible for the development and definition of voluntary standards at European level. CEN provides a platform for the development of European standards and other technical documents for various types of products, materials, services and processes. CEN supports standardization activities across a wide range of areas and sectors, including: air and space, chemicals, construction, consumer products, defense and security, energy, environment, food and feed, health and safety, health, information and communication technologies, mechanical engineering, materials, pressure equipment, services, intelligent life, transport, packaging, etc.

CEN has shown and shows that European standardization plays an important role in the development and strengthening of the European single market, and Europe as a political and social conglomerate. Indicative is the fact that every European standard is recognized throughout Europe, automatically becoming a national standard in 34 European countries, which allows businesses to sell their products or services to consumers on a single European market.

CEN, together with CENELEC and ETSI, is recognized by the European Union as the official standardization organization. The legal basis for this cooperation is set out in the EU Regulation 1025/2012, which in its final version came into force on January 1, 2013 [7]. CEN brings together the expertise of all its members, business and industry, other stakeholders, and aims to develop European standards for products, materials, services and processes. These European standards cover advanced technology and innovation. When European standards are correctly applied, quality, productivity and compatibility of goods and services are ensured. They help protect the environment, as well as the health and safety of consumers and workers. CEN also try to support the international standardization system and works closely with the International Organization for Standardization (ISO) through the Vienna Technical Cooperation Agreement between ISO and CEN (Vienna Agreement, 1991 [8]). The purpose of the Vienna Agreement is the simultaneous recognition of standards at the international and European levels through better information sharing and mutual representation at meetings. So, standardization activities should be carried out at the same level if at all possible. Now, an edited version of this Agreement is in operation, giving priority to international standardization and giving the ISO leadership a greater weight than previous versions. Also, a European standard based on the ISO standard can only be reviewed for ISO leadership regardless of their original origin.

In the world, including the EU, there are technical barriers to trade and they solve these problems through tools and requirements of standardization. According to the New Approach and Related Directives (for example, HRN EN 45020: 2004, Standardization and related activities - General vocabulary (ISO / IEC Guide 2: 1996; EN 45020: 1998) [9], there are «standardization», «regulation» and «technical regulation». There is an understanding of standardization as organizing active activities in the field of regulation, and regulations and technical regulations are understood by Europeans as regulatory acts. It is believed that the literal translation of «technical regulation» as «technical regulation» has led to the false understanding that in Europe there is a system of technical regulation along with standardization.

If we return to Ukraine's participation in the globalization process, especially in the economic sphere, we can say that today our country is represented in 9 international, European and regional organizations for standardization. In particular, Ukraine is a member of the International Organization for Standardization (ISO) in 1993 and became a member of the European Committee for Standardization (CEN) in 1997, the status of corresponding member (status envisaged especially for countries that intend to integrate into the EU).

Under the terms of membership, we can:

1) create a strong partnership that will provide some sectors of the economy privileged position in the European market;

2) get unlimited access to European standards (EN) for adoption (adaptation);

3) provide national stakeholders to become part of the European standardization process and join the leading European industries and companies.

The main benefits that we have to promote for stakeholders are:

1. Get direct access to the CEN and CENELEC repositories containing the accumulated expertise of the large CEN and CENELEC network of over 200,000 experts in their industry from 34 countries. 
2. There is an opportunity to promote technical harmonization that will allow interested individuals to enter the market with 600 million consumers and generate additional revenue.

3. Become an observer in an unlimited number of technical bodies and get the chance to form future EN by opening the door to a European single market for yourself.

4. Participate in the meetings of the CEN and CENELEC General Assembly as observers. Get first-hand information on strategic changes in the leading economic bloc.

We propose, based on European and international requirements, to build national standardization on the following principles:

1. Standards are voluntary and free to use. Unlike laws, standards are not legally and obligatory. They become obligatory, if they are mentioned in the contracts and / or legal acts.

2. The objective of standardization is to support Ukrainian legislation. The technical regulations should include references to standards that simplify the system and allow for faster and more automatic updating of the legislation when standards are updated.

3. Balancing between requirements that determine essential requirements for human health, environmental safety and product quality, and self-regulation opportunities for a business entity. They can freely choose how to comply with mandatory requirements, and automatically benefit from the presumption of conformity for free access to the European market.

4. Standards are useful and effective in determining liability. Even if the standards are not explicitly mentioned in the contract or regulatory act, they can be used to resolve legal disputes, especially in cases where it is a matter of responsibility for the quality of products or regarding the issue of the security component of standardization. Courts can use standards (in the wide sense) to decide whether the manufacturer really followed the verified rules and did «due diligence». Thus, standards can provide legal certainty in the application of liability.

5. Standards can help secure the rights of the consumer or other interested person. Technical standards play a special role in the field of commercial law, because interested parties can use them to help determine whether a product is defective or not. However, where the use of the standard was not mandatory, noncompliance does not necessarily mean that the product or service is defective. In the end, products can be manufactured properly, even where standards are not applied, especially when their use is voluntary.

6. Standards should ensure the rights of the parties to the contract or end-user (in particular, for troubleshooting, delivery of a fail-safe product, or compensation for any damage that arose due to lack of guaranteed characteristics). Standards can be used as a protector for damage detection and help identify the subject of responsibility and distribute losses.

7. Implementation of the promotion of standardization values for economic entities. In particular, to conduct an information policy and to emphasize the following advantages of standardization:

- improvement of their products and / or services;

- attraction of new clients;

- increase of competitiveness;

- increase of trust in business;

- reduction of errors;

- development and innovation cost reduction;

- guaranteeing the compatibility of their products with other components;

- facilitating the conclusion of contracts and fulfillment of obligations;

- facilitating the emergence of new markets;

- increase the chances of success in the application of standards within the entity of economic activity.

\section{REFERENCES:}

1. The official website of the International Organization for Standardization. URL: https://www.iso.org/ about-us.html (дата звернення: 12.11.2017).

2. Official information about the first 50 years of the ISO (1947-1997). URL: http://www.iso.org/iso/ ru/2012_friendship_among_equals.pdf (дата звернення: 12.11.2017).

3. ISO/IEC Guide 2:2004 Standardization and related activities - General vocabulary. URL: https://www.iso.org/ standard/39976.html (дата звернення: 12.11.2017).

4. ISO Guide 64:2008 Guide for addressing environmental issues in product standards. URL: https://www.iso.org/standard/41352.html (дата звернення: 12.11.2017).

5. The official website of the European Committee for Standardization. URL: https://www.cen.eu/about/ Pages/default.aspx (дата звернення: 12.11.2017).

6. European Standards Database. URL: https://standards.cen.eu (дата звернення: 12.11.2017). 
7. Regulation (EU) No 1025/2012 of the European Parliament and of the Council of 25 October 2012 on European standardisation. URL: http://eur-lex.europa.eu/LexUriServ/LexUriServ.do?uri=OJ:L:2012:316:0012: 0033:EN:PDF (дата звернення: 12.11.2017).

8. Agreement on technical co-operation between ISO and CEN (Vienna Agreement). URL: http://isotc.iso.org/ livelink/livelink/fetch/2000/2122/4230450/4230458/Agreement_on_Technical_Cooperation_between_ISO_a nd_CEN_(Vienna_Agreement).pdf (дата звернення: 12.11.2017).

9. EN 45020:2004, Standardization and related activities - General vocabulary (ISO/IEC Guide 2:1996; EN 45020:1998). URL: https://www.en-standard.eu/csn-en-45020-standardization-and-related-activitiesgeneral-vocabulary/ (дата звернення: 12.11.2017).

Попович Т. Г. Міжнародне бачення стандартизації як засобу регулювання діяльності суб’сктів господарювання в умовах нестабільності та глобалізації

На сьогодні стандартизація як один із проявів суспільно-економічної формації впливає на розвиток $i$ стан господарюючих суб'єктів. Основними факторами, які безпосередньо впливають на подальший розвиток національної стандартизаиії, є багатовекторна зовнішня політика, спрямована на інтеграцію Украӥни в Свропейський Союз, членство у Світовій Організачї Торгівлі, співпраия з іншими краӥнами світу. Аналізується розуміння стандартизаиії як організуючої активної діяльності в сфері упорядкування. Вказується на помилковість дослівного перекладу «technical regulation» як «технічне регулювання», яке привело до неправильного розуміння, що в Свропі діє система технічного регулювання поруч зі стандартизачією. Пропонується будувати національну систему стандартизації на основі блоків вимог, заснованих на міжнародному досвіді. Таких блоків вимог пропонується сім.

Ключові слова: стандартизація, технічне регулювання, регулювання, законодавчі акти, господарська діяльність, ліквідація бар'єрів у торгівлі, саморегуляція, добровільні та обов'язкові вимоги.

\section{СТВОРЕННЯ НАГЛЯДОВИХ РАД У ДЕРЖАВНИХ ПІДПРИЕМСТВАХ}

https://doi.org/10.32849/2409-9201.2018.18.42

Черненко О. А.,

кандидат юридичних наук, старший науковий співробітник НДІ приватного права і підприсмництва імені академіка Ф. Г. Бурчака НАПрН Украӥни

У статті розглядаються новели законодавства, що пов 'язані зі змінами в управлінні суб' єктами державного сектора економіки шляхом включення до органів управління згаданих підприємств такого органу, як наглядова рада.

Ключові слова: державне унітарне підприємство, державне корпоративне підприємство, наглядова рада, незалежні члени наглядової ради.

Законом України «Про внесення змін до деяких законодавчих актів України щодо управління об'єктами державної та комунальної власності» від 02.06.2016 р. було внесено суттєві зміни в управління суб'єктами державного та комунального секторів економіки шляхом включення до органів управління згаданих підприємств такого органу як наглядова рада, яка в межах компетенції, визначеної статутом підприємства та законом, контролює і регулює діяльність керівника підприємства.

Впровадження міжнародного досвіду корпоративного управління в Україні має сприяти підвищенню інвестиційної привабливості українських компаній на міжнародному ринку.

У науковій літературі домінує думка, що поява наглядових рад серед органів управління державними унітарними підприємствами сприятиме ефективній діяльності таких суб'єктів, оскільки управління стає більш відкритим. Впровадження інституту наглядових рад дає можливість залучати до управління професійних та незалежних фахівців, а це має підвищити економічні показники діяльності суб'єктів державного сектора економіки.

Окремі питання формування та функціонування наглядових рад розглядались у працях таких вчених, як: О. М. Вінник, Д. В. Задихайло, О. Р. Кібенко, І. В. Лукач, Д. І. Погрібний, І. В. СпасибоФатєєва та інші.

Метою дослідження у межах даної статті є огляд проблематики, пов'язаної зі змінами в управлінні суб'єктів державного сектора економіки, які відбулися з набранням чинності Законом України «Про внесення змін до деяких законодавчих актів України щодо управління об’єктами державної та комунальної власності».

Доцільність створення наглядової ради як органу контролю, що покликаний захищати інтереси власників компанії, визнана у багатьох країнах світу. В корпоративних підприємствах компетенцію наглядової ради розглядають 3 поділом на три групи: 1) повноваження щодо контролю за роботою виконавчого органу (укладення від імені товариства контракту з керівником, затвердження умов 